\title{
The Taiwanese Economy After the Miracle
}

An Industry in Restructuration, Structural Weaknesses and the Challenge of China

Philippe Chevalérias

\section{(2) OpenEdition}

\section{Journals}

Édition électronique

URL : http://journals.openedition.org/chinaperspectives/5301

DOI : 10.4000/chinaperspectives.5301

ISSN : 1996-4617

Éditeur

Centre d'étude français sur la Chine contemporaine

Édition imprimée

Date de publication : 15 septembre 2010

ISSN : 2070-3449

\section{Référence électronique}

Philippe Chevalérias, «The Taiwanese Economy After the Miracle», China Perspectives [En ligne],

2010/3 | 2010, mis en ligne le 01 septembre 2013, consulté le 28 octobre 2019. URL : http:// journals.openedition.org/chinaperspectives/5301 ; DOI : 10.4000/chinaperspectives.5301 


\title{
The Taiwanese Economy
}

\section{After the Miracle}

\author{
An Industry in Restructuration, Structural Weaknesses and the \\ Challenge of China
}

PHILIPPE CHEVALÉRIAS

The Taiwanese economic miracle is over. At the end of the 1980 s, changes in macroeconomic conditions forced Taiwanese industry to restructure. While it moved towards information technology, the island became increasingly tied to the mainland. By speeding up the integration of Taiwan with China by means of a China-Taiwan economic zone, President Ma Ying-jeou hopes to restart growth, but the economic and political consequences of the project are causing controversy.

$\mathrm{S}$ ince the end of the 1980s, relations with China have played a major part in the economic development of Taiwan. As a new land of opportunity for the island's investors, it helped many small and medium enterprises (SMEs) to maintain their competitiveness in overseas markets by allowing them to produce at lower cost. In so doing, it boosted the restructuring of the Taiwanese economy, which was then able, with the support of the authorities, to turn to more technological industries with higher added value. To major companies that were a bit constricted in Taiwan, China offered opportunities for expansion thanks to the enormous market located right on their doorstep. It supported the island's overseas trade by compensating for the fall in Taiwanese exports to the American and Japanese markets, whether in finished consumer products or in intermediate products, in the framework of a process of division of labour between the two shores of the Taiwan Strait. All this meant growing Taiwanese dependence on the Chinese economy.

This situation would probably be nothing unusual if Taiwan and China were two friendly countries simply seeking to benefit mutually from economic opportunities. However, relations between Taipei and Beijing are marked by a dispute that has remained unresolved since 1949, and which tends to link economic interests to political interests. This is why the project for a China-Taiwan economic zone in the framework of the ECFA (Economic Cooperation Framework Agreement / Liang'an jingji hezuo jiagou xieyi) proposed by Taiwanese President Ma Ying-jeou, who has held office since May 2008, is so sensitive and has aroused so much controversy. The policy towards the mainland followed by successive governments up to 2008, whether Kuomintang (KMT) or Democratic Progressive Party (DPP), has indeed led to a liberalisation of trade across the Strait, but this has happened gradually and in a limited fashion. Ma Ying-jeou, for his part, wants the ECFA to be the means to speedy and comprehensive liberalisation. Is this an appropriate answer to the difficulties of the Taiwanese economy? Is Taiwan not more likely to suffer more than it benefits from the economic power of its big neighbour? Couldn't economic integration with China compromise the island's political independence? These are some of the questions raised by the project.

After recalling how adjustment of the island's economy translated into massive foreign investment between 1988 and 1990, which laid the foundation for the conversion of Taiwanese industry to information technology (IT) on the one hand, and for closer economic relations with China on the other (two drivers in Taiwan's sustained economic growth during the 1990s), we will seek to explain to what extent the structural weaknesses of the Taiwanese economy hampered its growth during the 2000 s, particularly during the dotcom bubble of 2001 and the financial crash in 2008-2009. Finally, we will consider the relevance of the ECFA as an answer to the economic problems, as well as its implications on a political level.

\section{Industrial restructuring and increasing dependence on China}

After the Second World War, taking advantage of the legacy of 50 years of Japanese colonisation, as well as an active state policy of import substitution and then export promo- 
tion, (I) Taiwan experienced exceptional growth for 35 years (averaging 8.8 percent per year between 1951 and 1987), ${ }^{(2)}$ which was sometimes termed an economic miracle. ${ }^{(3)}$ However, at the end of the 1980s, this development model based on the export of labour-intensive goods, labour being a factor of production that was plentiful and cheap on the island until then, began to show signs of slowing down, with annual growth averaging 7.6 percent between 1988 and 1990. ${ }^{(4)}$

The island's companies at that time were confronted on the one hand with rising labour costs in Taiwan, mainly due to a shortage of manpower, ${ }^{(5)}$ and on the other with a strong rise in the Taiwanese currency (the New Taiwan Dollar or NTD) whose value, under pressure both internal (with an exchange rate that less and less reflected the technological progress boasted by local industry) and external (the US threatened protectionist measures unless Taipei adopted a monetary policy aimed at reducing the American trade deficit), ${ }^{(6)}$ rose by almost 40 percent over two years. ${ }^{(7)}$ This situation led to a fall in the competitiveness of Taiwanese export companies, which were facing new competition from Southeast Asia.

The economic adjustment necessitated by the change in macroeconomic conditions proved brutal. ${ }^{(8)}$ In the context of strong growth in foreign exchanges reserves and extreme market liquidity, pressure on the island's economy was released in the form of a wave of direct investment abroad, of which Southeast Asia, China, and the US received between two-thirds and three-quarters. ${ }^{(9)}$ While the choice of the Southeast Asian countries and China among the low-wage countries is explained by geographical proximity or cultural affinity (shared languages-Minnan ${ }^{(10)}$ and Mandarin-in China, large overseas Chinese communities in Southeast Asia), Taiwanese investment in the US was justified by the determination to establish markets for Taiwanese products and, a newer phenomenon, to acquire new technology. Indeed, the adjustment of the Taiwanese economy called for the transition from standardised to cutting-edge technology. As the market is often imperfect for this procedure, some of the island's companies chose to internalise $R \& D$ by investing on the other side of the Pacific. ${ }^{(I I)}$ In April 1989, the island's government finally opted for a flexible exchange rate mechanism: the Taiwanese currency found a balance at 26.2 NTD to the US dollar in 1989 , followed by 27.1 NTD to the US dollar in 1990. ${ }^{(12)}$ The stock market crash in October 1990 marked a temporary stop to the explosion in outward investment.

The pursuit of the restructuring took the form of a conversion of Taiwanese industry to IT. ${ }^{(1)}$ This was facilitated by the state through the stimulation of R\&D. ${ }^{(14)}$ In 1973, it
1. Joseph S. Lee, "The Role of State in Economic Restructuring and Development: The Case of Taiwan," Occasional Paper Series (CIER), No. 9403, April 1994, pp. 3-11.

2. GDP, constant 2006 prices in NTD. Calculation based on Statistical Abstract of National Account (SANA), Directorate General of Budget, Accounting and Statistics (DGBAS), Executive Yuan, ROC, http://eng.stat.gov.tw. This growth happened in the framework of a profound transformation of the Taiwanese economy: while foodstuffs (sugar, rice, tea, bananas, tinned goods, and seafood) accounted for 87.1 percent of the island's exports in 1952 , they amounted to only 1.2 percent in 1987 . They had been replaced by electric machines and appliances (25.2 percent), textile products (16.7 percent), plastic products (8.7 percent), and metal products (6 percent). Taiwan Statistical Data Book (TSDB), Council for Economic Planning and Development (CEPD), Taipei, ROC, 1988, pp. 228-229.

3. Denis Fred Simon, Michael Y.M. Kau (eds.), Taiwan: Beyond the Economic Miracle, Armonk, NY, M.E. Sharpe, 1992.

4. GDP at constant 2006 prices in NTD. Calculation based on SANA, DGBAS, op. cit.

5. Hui-lin Wu, Ke-jeng Lan, "Labor Shortage and Foreign Workers in Taiwan," Discussion Paper (CIER), No. 9109, October 1991, pp. 30.

6. US\$9.8 billion in 1984; 16 billion US\$ in 1987. TSDB, 1997, p. 194.

7. 39.9 NTD/US\$ in 1985; 28.6 NTD/US\$ in 1987. TSDB, 1997, op. cit., p. 4.

8. For a detailed analysis of the process of adjustment of the Taiwanese economy between 1988 and 1990, Philippe Chevalérias, La marche des firmes taiwanaises vers le continent chinois (1987-1997), Paris, INALCO, Doctoral thesis, October 1999, pp. 257-266.

9. 1988-1990, (US\$) total: 16.3 billion [a]; Southeast Asia (Indonesia, Malaysia, Philippines, Thailand, Vietnam): 8.7 billion (53.4 percent) [b]; China: 1.9 billion (11.7 percent) [c]; US: 1.1 billion (6.7 percent) [d]. In fact, it is extremely difficult to give a reliable estimate of each country's share of these investments, since the figures come from a range of sources: (total) balance of payments of Taiwan; (Southeast Asia, China) investment contracts signed by Taiwanese companies as registered in the host countries; (US) investment projects approved by the Taiwanese authorities, i.e., the Ministry of Economic Affairs (MOEA). However we prefer not to use the MOEA's figures for the investments in Southeast Asia (US\$849 million) [d] or in China (US\$647 million) [e] for the period 19881990 because many Taiwanese businessmen at the time invested in these regions without seeking the approval of the MOEA (Taipei still considered investment in China to be illegal), so it is certain that these figures are well below the reality. [a] Balance of Payments ROC, Taiwan District, The Central Bank of China; [b] Industrial Development and Investment Center (IDIC), MOEA, Taiwan; [c] Liang'an jingji tongji yuebao (LJTY) (Cross-Strait Economic Statistics Monthly), Mainland Affairs Council (MAC), Taiwan; [d] Statistics on Overseas Chinese and Foreign Investment, Outward Investment, Mainland Investment, Investment Commission, MOEA, Taiwan; [e] Lee-In Chen, "The Economic Reunion of Taiwan and the Mainland China: The Impact on Industrial Development," Discussion Paper (CIER), No. 9203, May 1992, p. 23.

10. "Minnan" is spoken in Fujian, where many Taiwanese originate.

11. Tain-Jy Chen, "Taiwan's Direct Foreign Investment: Patterns and Effects on Trade," paper presented at the Kyushu University International Symposium, Japan, Fukuoka, 2728 July 1992, p. 25.

12. TSDB, 1997, op. cit., p. 4.

13. The beginnings of the Taiwanese electronics industry go back to the 1960 s, when foreign companies, mostly American and Japanese, came to set up on the island in order to take advantage of relatively cheap local labour and a rapidly expanding domestic market. At that time, many of them chose to establish joint ventures that included technology transfer to their local partners. This was the case of the Japanese company Matsushita Electric (Songxia dianqi), which went into partnership in October 1962 with the Taiwanese company Jianlong Electric (Jianlong dianqi dian) for the production and sale first of radios, tape recorders, and microphones, and then of automatic cookers, electric fans, black and white TVs, etc. This joint venture was called Matsushita Electric Taiwan (Taiwan songxia dianqi). This was a first step, since in January 1966 the Japanese company created in Taiwan (with another Taiwanese partner, the Wang family) another joint venture called Taimatsu Industrial (Taisong gongye), which specialised in the manufacture of batteries. Other subsidiaries were set up on the island in 1976, 1981, 1990, 1992, 1995, and 2000 [a]. In the 1970s Taiwanese SMEs organised into networks began to manufacture electronic products such as calculators and telephones. Building on the experience acquired from foreign firms and a system of organisation into networks that was perfectly suited to short production cycles (flexibility and fast response capability), they moved up-market in the beginning of the 1980s with the manufacture of colour TVs and Personal Computers (PCs). [a] Information gathered by the author directly from Matsushita; [b] Tamio Hattori, Yukihito Sato, "A Comparative Study of Development Mechanisms in Korea and Taiwan: Introductory Analysis," The Developing Economies, Vol. XXXV, No. 4, December 1997, p. 351. 
founded the Industrial Technology Research Institute (ITRI), ${ }^{(15)}$ a publicly-funded body aimed at promoting innovation in Taiwan. In the framework of this institute was established a centre for the development of the electronics industry (dianzi gongye fazhan zhongxin), later renamed the Electronic Research and Service Organization (ERSO) (Gongyanyuan dianzi suo). In 1976 the ITRI signed an agreement with the US company RCA, which called for the transfer of Complementary metal-oxide-semiconductor (CMOS) technology that was to form the basis of the semiconductor industry on the island. ${ }^{(16)}$ Taiwanese engineers trained at RCA were appointed to the head of ERSO, where they carried out internal adaptation of this technology. This made possible the creation in 1979, under the impulse of the ITRI, of the United Microelectronics Corporation (UMC) (Lianhua dianzi), which was to specialise in the manufacture of silicon wafers (also called foundry wafers). The following year, taking Silicon Valley as a model, the island's government established the Hsinchu Science-based Industrial Park, ${ }^{(17)}$ where high-tech companies could avail themselves of inexpensive industrial infrastructure (sites, buildings, water, and energy sources), an attractive tax rate, and financial support for their $R \& D$.

These government initiatives encouraged a spin-off effect in the integrated circuit (IC) industry. ITRI was the origin of the establishment of another company in 1987, the Taiwan Semiconductor Manufacturing Corporation (TSMC) (Taiwan jiti dianlu), which became the first Taiwanese manufacturer of 6-inch silicon wafers ${ }^{(18)}$ and the first $\mathrm{OEM}^{(19)}$ subcontractor in the world for the manufacturing of IC chips. The same year, one of the first engineers recruited by the ITRI, Yang Tingyuan, went over to the private sector to found Winbond Electronics Corporation (WEC) (Huabang dianzi). A manufacturer of microprocessors (Intel 286, 386, 486) and silicon wafers at the end of the 1980s, WEC developed in the 1990s on the one hand by acquiring US firms such as the Californiabased Information Storage Devices (ISD), which specialised in IC vocal recording devices (1998), and on the other by partnerships with Japanese companies such as Toshiba for the design and manufacturing of DRAM (Dynamic Random Access Memory) and SRAM (Static Random Access Memory) chips (1995, 1996, 1999, 2000), and Sharp for the development of high-density flash memory (2001). ${ }^{(20)}$

Taiwan thus became a renowned IT centre. The manufacture of printed circuit boards and IC packages took off on the island in 1982; laptop manufacture in 1988, silicon wafers in 1989, computer disks and mobile phones in 1994. ${ }^{(21)}$ In 2008, 99 percent of netbooks, 92.5 percent of laptops and motherboards, 90.2 percent of cable modems, 89 percent of Wireless LAN network interface cards, 76.1 percent of voice-over IP routers, and 69.1 percent of Internet Protocol Phones sold on the world market were manufactured by Taiwanese companies. ${ }^{(22)}$

This profound transformation of Taiwanese industry went hand-in-hand with Taiwan's increasing economic dependence on China. In July 1985, after a 35-year ban, the island's government once again authorised trade between the two sides of the Strait ${ }^{(23)}$ on the condition that goods transit through a third territory (Hong Kong or Macau) and that the goods concerned not be detrimental to Taiwan's national security or its economy. ${ }^{(24)}$ This stimulated trade, which reached US\$1.5 billion in 1987. ${ }^{(25)}$ In July 1987, the lifting of martial law by Chiang Ching-kuo encouraged the island's companies, which were being pushed into off-shoring by the economic situation in order to reduce production costs, to invest on the other side of the Strait (US\$1.9 billion between 1988 and

14. Yeo Lin, "Industrial Structure, Technical Change, and the Role of Government in Development of the Electronics and Information Industry in Taipei, China," ERD Working Paper Series (Asian Development Bank), No. 41, May 2003, pp. 24-35.

15. Gongye jishu yanjiuyuan: Industrial Technology Research Institute.

16. ITRI (Taiwan), http://www.itri.org.tw.

17. Xinzhu kexue gongye yuanqu: Hsinchu Science Park.

18. ITRI (Taiwan), http://www.itri.org.tw.

19. Original Equipment Manufacturing. It is a contract under the terms of which a company manufactures a product designed by another company, which then markets it under its own brand.

20. WEC, http://www.winbond.com.tw. Among the initiatives of the ITRI stimulating a spinoff effect is the establishment of the Union of Notebook Manufacturers (Bijixing diannao lianmeng), i.e., 47 companies vertically integrated in the production process (1990), and the establishment of Vanguard International Semiconductor Corporation (VISC) (Shijie xianjin jiti dian/u), the first Taiwanese manufacturer of 8-inch silicon wafers (1994). ITRI (Taiwan), http://www.itri.org.tw.

21. TSDB, 2009, p. 113.

22. Institute for Information Industry (III), 2009 Quanqiu zitongxun chanye fazhan qushi xilie yanjiuhui (2009 Conference Series on the Development Trend of the World Information and Telecommunication Industry) - ICT Day, Taipei, III, MIC, 25 November 2008 (unpaginated document).

23. Trade between Taiwan and China was interrupted after the retreat of Chiang Kai-shek and the Kuomintang to Taiwan in December 1949, and the bombardment of Quemoy (Kinmen) by the Communist forces in 1954 and 1958. At the end of the 1970s, the economic reforms implemented by Deng Xiaoping in China restarted trade across the Strait via Hong Kong [the volume of which increased sevenfold between 1979 (US\$78 million) and 1984 (US\$553 million), while remaining illegal in the eyes of Taipei. LJTY (MAC, Taiwan), op. cit.

24. Three Basic Principles for Indirect Trade via Hong Kong and Macao (Dui Gang Ao diqu zhuankou maoyi san jiben yuanze).

25. LJTY (MAC, Taiwan), op. cit.

26. Note 11.

27. The martial law decreed in May 1949 by Chiang Kai-shek forbade all contact with the Communist enemy. Despite the risks, 80 investment contracts, amounting to US\$100 million were nonetheless signed by Taiwanese businessmen in China between 1983 and 1987. The abolition of martial law did not in any way mean that the island's entrepreneurs could invest freely on the Chinese mainland. Li Fei, Haixia liang'an jingmao guanxi (Economic and Trade Relations between the Two Sides of the Strait), Beijing, Duiwai maoyi jiaoyu, 1994, p. 158. 
1990), ${ }^{(26)}$ although still at their own risk. ${ }^{(27)}$ It was not until October 1990 that the Taiwanese government finally allowed investments on the mainland on condition that the capital was routed through a front company registered in a third territory and, following the example of the trade regulations, that Taiwan's security and economy were not harmed. ${ }^{(28)}$

While this relaxing of the law initially mainly benefited export-oriented SMEs in traditional sectors (shoes, clothing, domestic appliances, etc.), they were soon followed by the island's major companies, attracted both by the low cost of labour and the enormous market on their doorstep: Chung Shing Textile (Zhongxing fangzhi) (underwear), Inventec (Yingyeda) (electronic dictionaries and laptops), and Weichuan (Weiquan shipin) (food products) in 1991, President (Tongyi) (food products) in 1992, Kwang Yang Motor (Guangyang jiche) (scooters and motorbikes) in 1993, China Motor (Zhonghua qiche) (cars and trucks) in 1994, etc. ${ }^{(29)}$ Moreover, from the mid-1990s, the electronic and computer industries also began to invest massively on the other side of the Strait: from 20.5 percent between 1995 and 1997, their share of investment on the mainland rose to 46.8 percent between 1998 and 2000. ${ }^{\left({ }^{30)}\right.}$ This led to a boom in Taiwanese investment on the other side of the Strait: US\$17.1 billion between 1991 and 2000, i.e., an average of 1.7 billion a year for 10 years. ${ }^{(31)}$ The growing integration of economic activity across the Strait resulting from these investments led to soaring trade: US $\$ 5.2$ billion in 1990 and US\$31.2 billion in 2000. ${ }^{(32)}$

Thus over a 15 -year period China became an essential trading partner for Taiwan. ${ }^{(33)}$ While in 2000 China's share of Taiwanese imports remained relatively low (4.4 percent, as against 18 percent for the US and 28.2 percent for Japan), it had become the island's second largest export market, with 16.5 percent, behind the US (23.4 percent) but ahead of Japan (11.1 percent). ${ }^{(34)}$ The rapprochement, not to say the integration, between Taiwan and China increased further in the 2000s. Acquisition of membership in the World Trade Organisation (WTO) by the People's Republic of China and by Taiwan, on 16 December 2001 and 1 January 2002 respectively, led Taiwanese President Chen Shuibian to further liberalise trade between the two sides of the Strait: ${ }^{\left({ }^{35}\right)}$ in July 2002, he allowed the island's businessmen to invest "directly" on the mainland. ${ }^{(36)}$ The result was another wave of investment: US\$65.6 billion between 2001 and 2009, i.e, an average of US\$7.3 billion per year over nine years. ${ }^{(37)}$ Trade levels then showed a new record high: US $\$ 105.4$ billion in 2008. ${ }^{(38)}$ In 2002, Taiwan for the first time exported more to China (23.3 percent) than to the US
(20.2 percent). In 2006, for the first time it imported more from China (12.2 percent) than from the US (11.2 percent). All in all, China was gradually replacing the US and Japan: in 2009 it accounted for 30.5 percent of Taiwanese exports, ahead of the US (11.6 percent) and Japan (7.1 percent), and 14.1 percent of Taiwanese imports, still behind Japan (20.8 percent) but ahead of the US (10.4 percent). ${ }^{(39)}$

\section{The Achilles heels of the Taiwanese economy}

In view of the growth shown by Taiwan in the 1990s (an average of 6.2 percent per year between 1990 and 2000), ${ }^{(40)}$ the restructuring of the Taiwanese economy seems to have been successful. It also weathered the Asian financial crash of 1997-1998 fairly well: ${ }^{(4)}$ the rate of growth in 1998 was 3.5 percent $^{(42)}$ (as against a fall of 5.7 percent in South Korea, ${ }^{(43)}$ for example). However the 2000s showed more mixed results. In terms of the balance of trade, results were

28. Regulations Concerning the Management of Indirect Investment or Technological Cooperation on the Mainland (Dui Dalu diqu congshi jianjie touzi huo jishu hezuo guanli banfa).

29. Information gathered directly by the author from the companies.

30. Investment projects approved by the MOEA. Statistics on Overseas Chinese ... (Investment Commission, MOEA, Taiwan), op. cit.

31. Investment projects approved by the MOEA. LJTY (MAC, Taiwan), op. cit.

32. LJTY (MAC, Taiwan), op. cit.

33. In 1987, the US and Japan remained by far the biggest of Taiwan's trading partners: the former with 21.9 percent of the island's imports and 44.1 percent of its exports; the latter with 33.8 percent of its imports and 13 percent of its exports. At that time, China stood very far behind: 0.8 percent of imports; 2.3 percent of exports. (US, Japan) TSDB, 1997, op. cit., pp. 199 and 201; (China) LJTY (MAC, Taiwan), op. cit.

34. US, Japan: TSDB, 2009, op. cit., pp. 227 and 229; China: LJTY (MAC, Taiwan), op. cit.

35. In November 2001, he announced the guidelines of his mainland policy: "Active opening, effective management" (jiji kaifang, youxiao guanli).

36. In fact, entrepreneurs still had the possibility of investing "indirectly" through a front company in order to protect their capital. Jiun-mei Tien, "Policy implication of liberalizing direct investment in mainland China," Liang'an jingmao yuekan (LJY) (Straits Business Monthly) [Straits Exchange Foundation (SEF), Taiwan], August 2002, pp. 3-7.

37. Investment projects approved by the MOEA. LJTY (MAC, Taiwan), op. cit.

38. LJTY (MAC, Taiwan), op. cit.

39. (US, Japan) Bureau of Foreign Trade (BOFT, Taiwan), Trade Statistics, http://eweb.trade. gov.tw; (Chine) LJTY (MAC, Taiwan), op. cit.

40. GDP, constant 2006 prices in NTD. Calculation based on SANA, DGBAS, op. cit.

41. If the Taiwanese economy reacted fairly well to this crisis, it was because the island's industrial structure was dominated by SMEs, and these did not have an excessive debt ratio. Min-Hsu Chen, "How Could Taiwan Have Been Insulated from the 1997 Financial Crisis?", NPF Research Report (National Policy Foundation, Taiwan), 11 September 2001, http://old.npf.org.tw.

42. SANA, DGBAS, op. cit.

43. GDP, constant 2005 prices in won. Principal Economic Indicators (PEI), March 2010, Economic Statistics Department, The Bank of Korea, http://eng.bok.or.kr. 
better than in the previous decade: four years between US\$21.3 billion (2006) 29.3 billion (2009), and six years between US\$11.2 billion (2000) and 15.8 billion (2005) (in the 1990s there had been four years between US\$12.5 billion (1990) and 14.4 billion (1996), and six years between US\$7.4 billion (1998) and 9.8 billion (1992)). ${ }^{(4)}$ At the same time, growth slowed noticeably, to an annual average of 3.1 percent between 2000 and 2009. ${ }^{(4)}$ Actually, this figure needs to be interpreted with caution. Firstly, it conceals strong annual variations: six years between 3.7 percent (2003) and 6.2 percent (2004), one year at 0.7 percent (2008), and two years of negative growth (- 1.7 percent in 2001 and -1.9 percent in 2009). ${ }^{(4)}$ It also reflects to some extent the increasing maturity of the Taiwanese economy, with the island's macroeconomic conditions now similar to those of industrialised countries. Nevertheless, it remains symptomatic of the weaknesses the dotcom bubble of 2001 and the financial crash of 2008-2009 helped to reveal (as a comparison, growth in South Korea was 4 percent in 2001, 2.3 percent in 2008 and 0.2 percent in 2009). ${ }^{(47)}$ Another revealing sign of the difficulties faced by the island's economy is falling market share abroad. In the US, Taiwan fell from $7^{\text {th }}$ place (3.3 percent of the American market) in 2000 to $9^{\text {th }}$ place (1.8 percent of the American market) in 2009; and in Japan from $4^{\text {th }}$ place (4.7 percent of the Japanese market) to $8^{\text {th }}$ place (3.3 percent of the Japanese market). ${ }^{(48)}$ Taiwanese products' share of ASEAN imports ${ }^{(4)}$ fell from 4.9 percent in $2000^{\left({ }^{(5)}\right)}$ to 4.4 percent in 2009; ${ }^{(51)}$ in China's imports it fell from 11.1 percent in 2000 to 6.2 percent in 2009. ${ }^{(52)}$

These problems are the result of at least three structural weaknesses affecting the Taiwanese economy: unbalanced growth, over-dependence on foreign technology, and a shortage of internationally-recognised brands. Unbalanced growth appears in both the excessive weight of foreign trade and the sectoral and regional over-concentration of exports. During the 2000s, the contribution of foreign trade to economic growth was much greater than that of the domestic market: between 2000 and 2009, four-fifths of real growth was fed by net export growth, ${ }^{(3)}$ and only one fifth by growth in domestic demand. ${ }^{(54)}$ While this situation originates partly in the fact that Taiwan has traditionally depended on its foreign trade, it is also explained by lower increases in income during the 2000s than in the 1990s. Between 2000 and 2008, salaries rose by an average of only 0.2 percent per year (as against 5.5 percent between 1990 and 2000) in the information and communications sector, and average of only 0.3 percent per year (as against 5.4 percent in 1990-2000) in the accommodation and food services sector. ${ }^{(55)}$ National income per capita ${ }^{(56)}$ (based on constant 2006 prices in NTD) rose only by a yearly average of 1.1 percent during 20002009 (as opposed to 4.8 percent in 1990-2000), ${ }^{(57)}$ which is to say at a slightly slower rate than in South Korea (2.7 percent, ${ }^{(58)}$ in won at constant 2005 prices). ${ }^{(59)}$ Moreover, in 2009 , while the machine and electric equipment industry accounted for 46.8 percent of the island's exports (including 27.8 percent of electronic products), ${ }^{(60)}$ China, Hong Kong, the US, and Japan together received 59.8 percent of Taiwanese exports. ${ }^{\left({ }^{(1)}\right.}$

The second weakness in the Taiwanese economy lies in the fact that, despite the government's efforts to promote $R \& D$, Taiwan has remained in most cases dependent on American, Japanese, and even Korean companies for key technology. In the 1990s, the island had to import central processing units (CPUs) and random access memory (RAM), two

44. 1990-2008: TSDB, 2009, op. cit., p. 216; 2009: BOFT, Taiwan, Trade Statistics, op. cit.

45. GDP, constant 2006 prices in NTD. Calculation based on SANA, DGBAS, op. cit.

46. GDP, constant 2006 prices in NTD. SANA, DGBAS, op. cit.

47. GDP, constant 2005 prices in won. PEI, The Bank of Korea, op. cit.

48. MOEA (Taiwan), Quanqiu taishang fuwu wang (QTFW) (Website for Taiwanese entrepreneurs worldwide), http://twbusiness.nat.gov.tw.

49. Referring to the "ASEAN 5," Indonesia, Malaysia, Philippines, Thailand, and Singapore.

50. Guomaoju (BOFT, Taiwan), "Bashijiu nian duiwai maoyi fazhan gaikuang" (The Development of [Taiwanese] Foreign Trade in 2000), 5 July 2001, http://cweb.trade gov.tw.

51. Guomaoju (BOFT, Taiwan), "2009 nian duiwai maoyi fazhan gaikuang" (The Development of [Taiwanese] Foreign Trade in 2009), 26 May 2010, http://cweb.trade .gov.tw.

52. Total imports, Chinese Customs: QTFW (MOEA, Taiwan), op. cit.; (imports of Taiwanese products, MAC estimate) LJTY (MAC, Taiwan), op. cit.

53. Rate of growth in exports - rate of growth in imports.

54. Average annual growth rates: GDP $=+3.1$ percent; "net" exports $=+2.5$ percent; domestic demand (private consumption + public consumption + gross formation of fixed capital) $=+0.6$ percent. Calculation based on SANA, DGBAS, op. cit.

55. Average monthly salary per employee: information and communications, NTD 36,866 in 1990; NTD 62,759 in 2000; NTD 63,888 in 2008; accommodation and food services, NTD 15,448 in 1990; NTD 26,060 in 2000; NTD 26,747 in 2008. TSDB, 2009, op. cit., p. 41.

56. National income $(\mathrm{NI})=$ gross national product $(\mathrm{GNP})-$ taxes linked to production - consumption of fixed capital (= depreciation undergone by fixed capital).

57. SANA, DGBAS, op. cit.

58. Calculation based on PEI, The Bank of Korea, op. cit.

59. It should be pointed out, however, that GDP per capita measured in parity of purchasing power remained higher in Taiwan (US\$31,834) than in South Korea $(U S \$ 27,978$ ) in 2009. World Economic Outlook Database, http://www.imf.org.

60. MOEA (Taiwan), Statistics of Economic, Economic Indicators, http://www.moea gov.tw.

61. China: 30.5 percent; US: 11.6 percent; Hong Kong: 10.6 percent; Japan: 7.1 percent. (US, Japan) BOFT, Taiwan, Trade Statistics, op. cit:; (China, Hong Kong) LJTY (MAC, Taiwan), op. cit. Taiwan is doubly dependent on the American and Japanese markets: directly in the case of Taiwanese finished products exported to these two markets, but above all indirectly in the case of semi-finished Taiwanese products exported to China and Hong Kong, which after assembly are re-exported to the US and Japan. 
essential components amounting to at least half of the production cost of a computer. ${ }^{\left({ }^{(2)}\right)}$ In the beginning of the 2000s it was the technology of thin-film-transistor liquid crystal displays (TFT-LCDs), essential to the manufacture of desktops and laptops, that Taiwanese manufacturers lacked. Although the latter had acquired this technology from foreign (especially Japanese) firms (Acer (Hongji) from IBM Japan, Quanta Computer (Guangda diannao) from Sharp, Chunghwa Picture Tubes (Zhonghua yingguan) from Mitsubishi, HannStar Display (Hanyu caijing) from Toshiba, etc.), ${ }^{(63)}$ the Japanese and the Koreans were confident that they could maintain their technological advance, hence the necessity for the island's companies to import electronic equipment and components in large quantities. Between 2000 and 2008, Taiwan imported around US\$570 billion worth of electric machines and equipment (37.9 percent of the island's total imports). Key electronic components such as cathode valves and tubes, diodes and liquid crystals amounted to 42.5 percent (242 billion) of this, with over half of the components coming from Japan (18.1 percent), South Korea (17.5 percent), and the US (14.5 percent). ${ }^{(64)}$ Over this period, two of Taiwan's biggest trade deficits were with Japan and South Korea, amounting between 2000 and 2008, to US $\$ 220.7$ billion and 49.3 billion respectively. ${ }^{(65)}$ The third weakness in the Taiwanese economy is the virtual absence of recognised brands at the international level. The roots of this situation are doubtless to be found in the strategy adopted in the 1960s by most Taiwanese companies that developed in the shadow of the multinationals-especially American and Japanese-with which they signed OEM contracts, and which gave them access to new technologies and to distribution networks abroad. While some subsequently moved on to Original Design Manufacturing (ODM) contracts that allowed them to take on product design ${ }^{(6)}$ as well, very few adopted an Original Brand Manufacturing (OBM) strategy calling for the development of their own brand (Acer and Asus-Huashuo) are two examples in the IT industry, but they are exceptions). Moreover, even if they did so, they rarely gave up their OEM and/or ODM contracts. ${ }^{(6)}$ While this model allowed the island's SMEs to develop what became for them a kind of intangible asset-the flexibility to react rapidly to market stimuli and the ability to satisfy client demands in terms of price, quality and delivery deadlines ${ }^{(68)}-$ it usually kept them under the control of their clients, who were careful to maintain their advantage in terms of technology and/or marketing.

These Achilles heels have made the Taiwanese economy extremely sensitive to any change in the international environ- ment. The weakness of internal demand prevents the domestic market from properly absorbing shocks from outside. In the 1990s, while investing in China allowed the island's entrepreneurs to meet competition by increasing their production capacity and reducing costs through economies of scale, they did not succeed in gaining genuine control of key technologies or markets. ${ }^{(69)}$ The need to import technology is a weight on the balance of trade and therefore on growth. In the context of increased competition on the world market (China, Northeast Asia, and Southeast Asia, as well as Central America, South America, and Eastern Europe), Taiwanese companies have had trouble maintaining market share abroad. In the US and Japan, low and middle-range Taiwanese consumer goods are increasingly uncompetitive compared to Chinese products: China climbed in the US from $4^{\text {th }}$ place in 2000 (8.2 percent of imports) to first place in 2009 ( 19 percent); and in Japan from $2^{\text {nd }}$ place in 2000 (13.8 percent) to $1^{\text {st }}$ place in 2009 (22.2 percent) in Japan. ${ }^{(70)}$ In China, although some Taiwanese firms have managed to promote their own brands, like Ting-Hsin with their Kang Shih Fu instant noodles, Chinese consumers tend to favour major Japanese brands (in the case of high earners), or Korean brands such as Samsung or LG (for average and low earners). ${ }^{(71)}$

In the face of the island's economic problems, President Ma Ying-jeou has launched the idea of an economic zone bringing China and Taiwan together under the ECFA, a framework agreement for China-Taiwan economic cooperation. According to the Kuomintang government, the agreement

62. Yeo Lin, 2003, op. cit., p. 21.

63. Charles S. Lee, "Headlong Plunge," Far Eastern Economic Review, 10 June 1999, pp. 84-86.

64. TSDB, 2009, op. cit., pp. 245 and 250 .

65. Taiwan's trade deficit with Saudi Arabia (totalling US\$55.9 billion between 2000 and 2008 ) is essentially attributable to energy imports. Calculation based on TSDB, 2009, op. cit., pp. 222-226.

66. At the end of the 1990s, Quanta Computer designed and manufactured PCs for IBM Dell, Hewlett-Packard, Apple, and Siemens. China News, 5 February 1999, p. 7.

67. Even after developing its own brand, Acer continued to work as a subcontractor for a dozen foreign companies, including Fujitsu, Hitachi, and IBM. Charles S. Lee, 1999, op. cit., p. 84.

68. Tain-Jy Chen (ed.), Taiwanese Firms in Southeast Asia: Networking Across Borders, Cheltenham, UK, Northampton, MA, US, Edward Elgar, New Horizons in International Business, 1998, pp. 36-37 and 50-52.

69. Lai Jianyu, "Zouchu chao 'men' shi nian xunzhao Taiwan xin pingheng yaofang" (In search of a new remedy to come out of [a period of] ten years of deep gloom and provide Taiwan with balanced development, Tianxia zazhi (CommonWealth), No. 439, January 2010, http://www.cw.com.tw.

70. QTFW (MOEA, Taiwan), op. cit.

71. Taiwan Institute of Economic Research (TIER), "Jinrong haixiao hou Taiwan chanye zai chufa" (After the Financial Tsunami, the Taiwanese Economy Starts up Again), Taipei, TIER, Jingji pinglun (Economic Assessment), Taijing shelun (TIER Editorial), January 2010, http://www.tier.org.tw. 
will help normalise economic relations between the two sides of the Strait, while also preventing Taiwan from being marginalised by the free trade areas being set up around the ASEAN: ${ }^{(72)}$ ASEAN + 1 (China), ASEAN + 3 (China, Japan, South Korea), and even ASEAN + 6 (China, Japan, South Korea, India, Australia, New Zealand). ${ }^{(73)}$ The island's government hopes that the ECFA will be a first step allowing Taiwan to participate in the economic integration emerging in the Asia Pacific region. However, the project is far from being unanimously supported in Taiwan, where the opposition, led by the Democratic Progressive Party (DPP) and the Taiwan Solidarity Union (TSU), ${ }^{(74)}$ are calling for a referendum on the issue. Indeed, the ECFA raises a number of questions on both the economic and political level.

\section{ECFA, an economically unsatisfactory solution}

While it is true that the 2000s saw an increase in the number of free trade areas around the world, ${ }^{(75)}$ it is too simplistic to attribute the island's economic problems only to the fact that Taiwan has to a large extent remained outside this trend. It is indeed true that free trade agreements such as those signed and being applied-between the ASEAN and China in 2005 and between the ASEAN and South Korea in 2007-contribute to reducing the competitiveness of Taiwanese products in the region: in 2009, South Korea overtook Taiwan in Southeast Asia (ASEAN 5) with a 5.1 percent market share (4.4 percent for Taiwan), when Taiwan was ahead in 2007 with 5.2 percent market share (4.7 percent for South Korea). ${ }^{(76)}$ One might therefore think that projects such as "ASEAN+3" and "ASEAN+6" might further disadvantage Taiwanese business. Yet the situation is more complex than it appears.

Firstly, these free trade agreements have up to now operated only on the margins. On the one hand, the proportion of Taiwanese products among China's imports began to fall from 1997 onward (15.8 percent in 1997, 11.1 percent in 2000, 8.5 percent in 2005, 6.2 percent in 2009). ${ }^{(77)}$ On the other, the island's exporters are not as isolated as all that. For example, under the Information Technology Agreement (ITA) signed in the framework of the WTO, a considerable portion of Taiwanese exports to the US, Japan, the ASEAN, China, Hong Kong, South Korea, etc., are already exempt from tariff barriers. ${ }^{(78)}$ In other words, the slowing of growth in Taiwan in the 2000s is no doubt explained not so much by the island's marginalisation from the current movement towards regional economic integration, as by the structural weaknesses of the Taiwanese economy. From this point of view, the ECFA is far from providing an overall solution, which would more likely involve the construction of a more balanced development model that would seek among other things to restore the importance of domestic demand, to diversify both economic activity (tourism, green energy, etc.) and export markets, ${ }^{(79)}$ to develop innovative technology that would allow the manufacture of more profitable upmarket products with less competition on the world market, and to promote Taiwanese brands abroad.

Secondly, while all else being equal, the ECFA should be profitable to the island's exporters because of the planned reduction in entry duties to the Chinese market, particularly in sectors such as petrochemicals, steel, and textiles, the collateral effects it could produce on the Taiwanese economy are far from insignificant. Farmers, as well as Taiwanese SMEs in traditional sectors that produce mainly for the domestic market (such as hosiery, shoes, bags, consumer electronics, etc.), are in danger of being hit by the massive arrival of Chinese products in Taiwan. ${ }^{(80)}$ Symbolising this question is opposition to the ECFA by sock manufacturers in Shetou County's Changhua District. The Taiwanese government, aware of this, has promised not to add to the list of Chinese agricultural products that can be imported to the island, ${ }^{(81)}$ and to allow for an adjustment period for the most

72. The founding members of the ASEAN were Singapore, Malaysia, Indonesia, the Philippines and Thailand. The organisation was subsequently joined by Brunei, Vietnam, Cambodia, Laos and Myanmar (Burma).

73. Gao Chang, Li Tiansheng, "ECFA yu liang'an jingmao guanxi zhanwang" (Prospect of economic and trade relations between the two sides of the strait in the framework of the ECFA), LJY (SEF, Taiwan), March 2010, http://www.seftb.org.

74. Taiwan tuanjie lianmeng: Taiwan Solidarity Union.

75. According to the WTO, 148 agreements (Free Trade Agreement, Regional Trade Agreement) for the establishment of free trade areas were signed worldwide between 2000 and 2008. Jingjibu (MOEA, Taiwan), "Liang'an jingji xieyi zhi neihan ji keneng yingxiang" (Contents and possible effects of the ECFA), LJY (SEF, Taiwan), March 2010, http://www.seftb.org.

76. Guomaoju (BOFT, Taiwan), 26 May 2010, op. cit:; Guomaoju (BOFT, Taiwan), "2007 nian Zhonghua minguo duiwai maoyi fazhan gaikuang" (The development of the Republic of China's foreign trade in 2007), 19 May 2008, http://cweb.trade.gov.tw.

77. (Total imports, Chinese Customs) QTFW (MOEA, Taiwan), op. cit.; (imports of Taiwanese products, MAC estimate) LJTY (MAC, Taiwan), op. cit.

78. Taiwan was among the first 29 initial signatories of the ITA (there are now 70). The objective of this agreement, initially signed in Singapore in December 1996, is to promote the development of IT by abolishing customs duties on products of the sectors concerned. "Information Technology Agreement - Introduction" (http://www.wto.org/ english/tratop_e/inftec_e/itaintro_e.htm); "Ministerial Declaration on Trade in Information Technology Products" (http://www.wto.org/english/docs_e/legal_e/ itadec_e.htm), 3 June 2010.

79. TIER, "Jinrong haixiao hou Taiwan chanye zai chufa," January 2010, op. cit

80. Coral Lee "L'ECFA, la solution miracle ?", Taiwan aujourd'hui, vol. 26, no. 9, September 2009, pp. 17-19.

81. Gao Chang, Li Tiansheng, 2010, op. cit. 
threatened industries. ${ }^{\left({ }^{(2)}\right)}$ There is also the example of Hong Kong, where rapprochement with China certainly benefited local tourism, but also drained part of the territory's capital and talent towards the mainland. ${ }^{(83)}$ The services sector, which in 2008 accounted for no less than 73.3 percent of GDP and 58 percent of jobs, ${ }^{(84)}$ also feels threatened. The fear is that if Taiwan agrees to recognise Chinese qualifications and allows Chinese workers to sit competitive examinations allowing them to practice law, accountancy, or architecture on the island, there will be a fall in the quality of services provided as well as in incomes. ${ }^{\left({ }^{(5)}\right)}$ Lastly, there remains the question of whether signing the ECFA will in fact allow Taiwan to sign free trade agreements with other countries. At the moment there is no certainty, although during the first televised debate on the ECFA on 5 April 2010 the head of the Taiwanese negotiating team, Huang Chih-peng, stated that a number of States - which he did not wish to name - had already made it known that they were ready to discuss such a prospect with Taipei if political tensions between the two sides of the Strait diminished. ${ }^{(80)}$ Consequently, the effects of the ECFA on the Taiwanese economy as a whole can be objectively assessed only by weighing up the advantages in terms of regional integration against the disadvantages in terms of competition on the domestic market and of the draining of resources.

\section{A politically sensitive agreement}

Controversial on an economic level, the ECFA is also extremely sensitive on a political level, for while the Taiwanese certainly wish to take advantage of the Chinese economy for their own development, they are also afraid that China may seek to control the island through the economy. ${ }^{(87)}$

Up to now, it must be recognised that Chinese economic power has proved to be more of an opportunity than a threat to Taiwan. It is true that the move towards liberalisation of trade across the Strait, which began with the recognition by the Taiwanese government of indirect trade (1985) and investment (1990), followed by the establishment of the extraterritorial maritime centre at Kaohsiung (Gaoxiong gang jingwai hangyun zhongxin), which made possible the first semidirect sea connections between the two sides in April 1997, ${ }^{(88)}$ and then by the opening of "small" direct connections (xiao san tong) in January 2002, ${ }^{(89)}$ led to an upsurge in Taiwanese investments on the mainland: 37,771 Taiwanese companies invested US\$82.7 billion between 1991 and 2009 according to official Taiwanese sources. ${ }^{(90)}$ It is equally true that the island's increased dependence on China resulting from these investments has not in any way hindered the implementation of democratic reforms in Taiwan, and that these have tended to give the island more independence by institutionally distancing the two sides of the Strait.

Why then does the ECFA produce political waves? Probably because it tends to accentuate the threat represented by China. While in a way it forms part of the move towards trade liberalisation across the Strait that began in the 1980s, ${ }^{(91)}$ it goes much further than anything done previously. The agreement on financial cooperation signed in April 2009 should allow China to invest massively in Taiwan ("direct" or "portfolio" investment), including in a sector as sensitive as property. ${ }^{(92)}$ To Beijing, the economy is an instrument in the service of political ambition. The Provisional Regulation on the Development of Trade with Taiwan, ${ }^{(93)}$ dating from May 1979, already stated: "The objective of trade with Taiwan by joining the world of industry and commerce is to promote economic union between the two sides of the Strait, and thus the return of Taiwan to the fold of the Mother Country [...]" ${ }^{(94)}$ The pressure brought to bear by Beijing on ASEAN countries to discourage them from signing free trade agreements with Taiwan is part of the same strategy. The ECFA project is an opportunity for the Communist government to lay the foundations for economic reunification, the first stage on the road to political reunifica-

82. Guomaoju (BOFT, Taiwan), "Liang'an jingji hezuo jiagou xieyi jieshao" (Introduction to the ECFA), 28 September 2009, http://cweb.trade.gov.tw.

83. Coral Lee, 2009, op. cit., pp. 18-19.

84. TSDB, 2009, op. cit., pp. 35 and 60

85. Ziyou shibao, "Qi zhi chuan chan, lü: ECFA chongji 321 wan bailing" (Are traditional industries the only ones concerned? The Greens (= DPP + TSU) say NO: the ECFA threatens 3.21 million white collar workers), Ziyou shibao, 6 April 2010.

86. Taiwan Info, "ECFA: the government is struggling to convince," 6 April 2010, http://taiwaninfo.nat.gov.tw.

87. This was not a new fear, since former President Lee Teng-hui in September 1996 was already exhorting businessmen not to invest too much on the mainland with the slogan: "No haste, be patient!" (jie ji yong ren).

88. Between Kaohsiung and Fuzhou / Xiamen, on Lee Teng-hui''s initiative.

89. Between Quemoy (Kinmen) / Matsu and Quanzhou, on Chen Shui-bian's initiative.

90. Investment projects approved by the MOEA. LJTY (MAC, Taiwan), op. cit. These figures are certainly an under-estimate.

91. The agreements on direct air and sea links signed by the Straits Exchange Foundation (SEF) (HaijihuI) and the Association for Relations Across the Taiwan Straits (ARATS) (Haixiehul) in November 2008 are from this perspective no more than a further step in the process of normalisation of economic relations between Taiwan and China. Gao Chang, Li Tiansheng, 2010, op. cit.

92. Gao Chang, Li Tiansheng, 2010, op. cit

93. Guanyu kaizhan dui Taiwan maoyi de zanxing guiding.

94. The objective of reunification was firmly recalled by the Chinese government in March 2005 by means of the Anti-Secession Law (Fan fenlie guojia fa), which established the principle of military intervention against Taiwan in case of a declaration of independence. 
tion. Moreover, while the Kuomintang government presents the ECFA as essential for the future of the Taiwanese economy, the Communist government for its part does not refer to the imperious necessity of this agreement for the future of the Chinese economy. ${ }^{(95)}$ To Beijing, it clearly has a political objective: that of reunification.

It is true that the economic rapprochement between Taiwan and China is a long-term trend that goes beyond the partisan interests of the Kuomintang or the DPP. Firstly, investment on the Chinese mainland satisfies a real need for Taiwanese companies. Secondly, the process of normalisation of economic relations across the Strait is incumbent on Taiwan since the island joined the WTO. Finally, the growing power of the Chinese economy on the world scene makes it unavoidable, whatever the country involved. However, the ECFA as such has major political significance. Of course it does not automatically imply reunification between the two sides of the Strait. By hooking Taiwan "economically" to China, however, it might reduce the probability of Taiwanese de jure independence in the future. This is why the ECFA appeals more to supporters of unification and worries supporters of the island's independence.

The televised debate on 25 April 2010 between Ma Yingjeou and the president of the DPP, Tsai Ying-wen, dealt at length with the economic stakes of the ECFA, with Ma underlining in particular the urgency of such an agreement and its advantages in terms of commercial benefits and renewed investment, while Tsai came out against any hasty action in order to leave time for fragile local industries to adjust, and in favour of trying to rebalance the island's export trade in the multilateral framework of the WTO. Nonetheless, during this debate the President of the Republic himself recognised the political dimension of the agreement when he recalled his commitment to "protect the sovereignty of the Republic of China (and) to protect Taiwan's dignity" (hanwei Zhonghua minguo zhuquan, hanwei Taiwan zunyan). ${ }^{(96)}$

The ECFA, which the Kuomintang government presents as a purely economic agreement, could thus eventually give rise to new political tension. If Ma Ying-jeou maintains his official policy as symbolised by the slogan "No reunification, no independence, no conflict" ( $b u$ tong, $b u d u, b u w u$ ), then the ECFA contains the seeds of misunderstanding between the Kuomintang and the Chinese Communist Party. On the other hand, if the hope of Ma Ying-jeou (and of the Kuomintang) is for the reunification of Taiwan with China, then the ECFA contains the seeds of misunderstanding between the Kuomintang and the population of Taiwan, the majority of whom are opposed to the idea.

\section{Conclusion}

In view of the history of relations between the two sides of the Strait, the economic integration of Taiwan with China is not an exceptional phenomenon. Over past centuries, the island has made several return journeys within the Chinese economic sphere. ${ }^{(97)}$ Spurred by economic forces and business needs, the liberalisation of trade across the Strait underway over the past 25 years has also been globally beneficial to Taiwan in that it has helped the island's entrepreneurs face evolving macroeconomic conditions and the restructuring of Taiwanese industry. But this movement has its drawbacks. On the one hand, by enabling the maintenance of relatively high growth during the 1990s, it helped hide structural weaknesses in the Taiwanese economy that only became visible in the major recessions of the 2000s. On the other hand, by making the island increasingly economically dependent on the Chinese mainland, it revived the debate on the question of Taiwan's independence.

While President Ma Ying-jeou's project for a China-Taiwan economic zone is likely to help kick-start growth in Taiwan by generating investment on both sides of the Strait, it nonetheless has several major downsides. Firstly, it does not directly tackle the weaknesses afflicting the island's economy. Secondly, its overall economic impact remains uncertain. Everything will depend on how the Kuomintang government negotiates the content of the ECFA, which for the moment is merely a framework to be gradually filled out. Prudent (or perhaps worried?), Taiwan has already asked the Chinese government to insert a clause allowing interruption of the process in case of failure to respect the terms of the agreement. ${ }^{(98)}$ Finally, the ECFA puts the Taiwanese government in a position of weakness in relation to the $\mathrm{Com}$ munist government to the extent that the negotiations are lopsided: not only is China much more of an economic heavyweight than Taiwan, but the Chinese authorities continue to threaten the island militarily.

95. Indeed, Taiwan's share of China's foreign trade is falling: in 2009, Taiwan accounted for 6.2 percent of Chinese imports (as against 11.1 percent in 2000) and 2 percent of Chinese exports (as against 2.5 percent in 2000). (Total imports and exports, Chinese Customs) QTFW (MOEA, Taiwan), op. cit:; (Imports and exports of Taiwanese products, MAC estimate) LJTY (MAC, Taiwan), op. cit.

96. Luo Tianbin, "Ma Yingjiu: 'Bu huoyi ningke bu qian'” (Ma Ying-jeou: 'If [the ECFA] was not beneficial [to Taiwan], I would prefer not to sign [it]'), Ziyou shibao, 26 April 2010; Su Yongyao, "Cai Yingwen: 'Xiang Zhong qingxie tai maojin'” (Tsai Ying-wen: 'It is unwise [for Taiwan] to turn too much to China'), Ziyou shibao, 26 April 2010.

97. Lin Manhong, Si bai nian lai de liang'an fenhe - Yi ge jingmao shi de huigu (400 Years of separation and union - A retrospective of economic and trade relations between Taiwan and the Chinese mainland), Taipei, Zili wanbao wenhua, Taiwan lishi da xi, 1994 pp. 10-50.

98. Guomaoju (BOFT, Taiwan), 28 September 2009, op. cit. 
For all that, does the ECFA pose a real political danger to Taiwan? Probably not in terms of domestic politics: Taiwan's democracy is now well established and is not likely to be called into question. The public will, moreover, speak out during the legislative and presidential elections in 2012, with the prospect of a change in policy towards the mainland if the opposition wins. The ECFA could, however, influence the island's foreign policy by orienting it primarily towards China, and incite the Taiwanese authorities to keep a low profile in order not to irritate a "partner" who is all the more demanding for being in a strong position.

\section{Glossary}

Bïixing diannao lianmeng 筆記型電腦聯盟

bu tong, bu du, bu wu 不統、不獨、不武

Changhua 彰化

dianzi gongye fazhan zhongxin 電子工業發展中心

Dui Dalu diqu congshi jianjie touzi huo jishu hezuo guanli banfa 對大陸地區從事間接投資或技術合作管理辦法

Dui Gang Ao diqu zhuankou maoyi san jiben yuanze 對港澳地區轉口貿易三基本原則

Fan fenlie guojia fa 反分裂國家法

Gaoxiong gang jingwai hangyun zhongxin 高雄港境外航運中心

Gongyanyuan dianzi suo 工研院電子所

Gongye jishu yanjiuyuan 工業技術研究院

Guangda diannao 廣達電腦

Guangyang jiche 光陽機車

Guanyu kaizhan dui Taiwan maoyi de zanxing guiding 關於開展對㗌灣貿易的暫行規定

Haijihui 海基會

Haixiehui 海協會

hanwei Zhonghua minguo zhuquan, hanwei Taiwan zunyan 捍衛中華民國主權、捍衛㗌灣尊嚴

Hanyu caijing 瀚宇彩晶

Hongji 宏碁

Huabang dianzi 華邦電子

Huang Chih-peng 黄志鹏

Huashuo 華碩

Jianlong dianqi dian 建隆電氣店 jie ji yong ren 戒急用忍

jiji kaifang, youxiao guanli 積極開放、有效管理

Kang Shih Fu 康師傅

Liang'an jingji hezuo jiagou xieyi 兩岸經濟合作架構協議

Lianhua dianzi 聯華電子

Matsu 馬祖

Minnan 閩南

Quanzhou 泉州

Quemoy (Kinmen) 金門

Shetou 社頭

Shijie xianjin jiti dianlu世界先進積體電路

Songxia dianqi (Matsushita denki) 松下電器

Taisong gongye 薹松工業

Taiwan jiti dianlu 臺灣積體電路

Taiwan songxia dianqi 臺灣松下電器

Taiwan tuanjie lianmeng 薹灣團結聯盟

Ting-Hsin 頂新

Tongyi 統一

Weiquan shipin 味全食品

xiao san tong 小三通

Xinzhu kexue gongye yuanqu 新竹科學工業園區

Yang Ting-yuan 楊丁元

Yingyeda 英業達

Zhonghua qiche 中華汽車

Zhonghua yingguan 中華映管

Zhongxing fangzhi 中興紡織 